\title{
INFORMATIONAL ASYMMETRY IN PUBLIC PARTICIPATION ON ENVIRONMENTAL MONITORING IN INDONESIAN REGULATION: A PRELIMINARY DISCOURSE
}

\author{
Deni Daniel $^{1 *}$, Palupi Habsari ${ }^{1}$ \\ ${ }^{1}$ Faculty of Law, Universitas Indonesia, Depok 16424, Indonesia \\ (Received: July 2018 / Revised: September 2018 / Accepted: January 2019)
}

\begin{abstract}
Public participation has been viewed as a crucial component in environmental management. Public participation enables the community to inform the project proponents and government agencies on local knowledge and aspiration to be considered in the decision-making process. Based on our literature review we found that effective participation in monitoring might be hampered by informational asymmetry and the opportunistic nature of firms. In the case of Indonesia, little has been discussed on the possible informational asymmetry on the public participation process in environmental management. This paper aims to give a normative analysis of the current regulation of public participation in Indonesia to identify possible informational asymmetry that might give a barrier to effective monitoring. Our discussion found that there are still gaps in access to relevant information in the current mechanism of public participation. This is due to a prematurely informational disclosure and the lack of projects and decisions follow-up towards the community by both firms and government agencies. This set a barrier for the community to obtain credence information which comprised of the firms' environmental requirements and obligations and the highly technical aspects of environmental monitoring. We suggest a proper way to address this obstacle by reforming public participation regulation.
\end{abstract}

Keywords: Environmental impact assessment; Environmental monitoring; Indonesia; Informational asymmetry; Public participation

\section{INTRODUCTION}

Environmental management that previously depends on governments' and experts' decision is now shifting toward a more democratic system which brings back the public into core decision making. (Salomons \& Hoberg, 2014; Brombal, et al., 2017). As observed by Purnama (2003), this changes has also taken its toll in Indonesia. Consequently, the changes have placed public participation as an essential role in environmental governance in Indonesia. Indonesia has undergone several phases of incorporating public in environmental decision through Environmental Impact Assessment (EIA), beginning with the limited access toward decision making, to a one-way public announcement, to a more direct public participation by representing communities in assessment team in environmental decision making (Chen, 2013). To sum up, public participation in environmental management in Indonesia is not separated from the emergence of evidence-based policy and EIA.

\footnotetext{
*Corresponding author's email: denidaniel@live.com, palupihabsari1997@gmail.com
} 
Public participation has often been widely discussed in the context of EIA (Almer \& Koontz, 2004; Bawole, 2013; Chen, 2013; Cunningham \& Tiefenbacher, 2008; Nadeem \& Fischer, 2011; Hughes, 1998; Glucker et al., 2013). As cited by Glucker et al. (2013), Hughes (1998) described the participation in EIA as "...a process which brings citizens or organizations affected by a proposed project to influence decision-making." Numerous literature emphasize the effective public participation could bring to the environmental governance (Isaacson, 1986; Kraft, 1988; Fiorino, 1990; Creighton, 1983; Laird, 1993; Kasperson et al., 1992). Public involvement shows a better result of public information received, showing win-win potential to all party and building sustainable decisions (Newig \& Fritsch, 2009). Public participation in decision-making also develops a sense of community's attachment towards the decisions. For instance, public participation in EIA leads to a more comprehensive understanding of the proposed project as well as its impact (Shepherd \& Bowler, 1997). By that mean we can assume that the public still have a vital role in post-project monitoring to ensure compliance (Shepherd, 1997). Periodically, the public can measure the efficiency and implementation of mitigation as well as giving the feedback — as the project runs (Shepherd \& Bowler, 1997; Shepherd, 1997).

In this paper, we view public participation not only in the scope of project planning but extends up to project implementation, specifically monitoring. The idea of public participation in the environmental monitoring system is commonly referred to the literature as Community-Based Monitoring (CBM). As noted by Conrad \& Daoust (2008), Whitelaw et al., (2003) described $\mathrm{CBM}$ as "process where different stakeholders cooperate to monitor, track and respond to the issues of common problems in the community." Even though public participation in monitoring practices allows a more cost-effective alternative to government employee monitoring (Whitelaw et al., 2003), increase monitoring capacity and encourages the collaboration of diverse stakeholders (Conrad \& Daoust, 2008), some barriers render the public participation in monitoring ineffective. The significant barrier in public participation is the lack of knowledge and expertise which results in the inability to understanding the complex technical details of environmental management. Meanwhile, information regarding environmental management requires interpretation and analysis that seems obscure to the lay public. This mismatch, in turn, prevents the public from interacting and participating effectively (Hartley \& Wood, 2005). The rationale for this can be traced to the literature on economics discussing informational asymmetry. In this context, Information asymmetry in environmental monitoring will refer to Akerlof's (1970) seminal work on Market for Lemons and Arrow's (1971) on Moral Hazard. The model is then extended and contextualized by Comyns et al., (2013) applicable to environmental reporting. Borrowing from typologies of goods, Comyns et al. (2013), classify three types of information using which comprised of: search information; experience information; and credence information. Based on this, we argue that informational asymmetry may be used to shed light on a more effective public participation in environmental monitoring.

In cases of Indonesia, some literature has also asserted several weaknesses in Indonesia public participation in EIA. Hindrayani (2018) did a study which indicates that: the determination of community representatives based on the criteria of the impacted communities is not explicitly described; suggestions, opinions, and responses to the environmental impact management are not well implemented by the project proponent; implementation of the environmental management of other licensed activities affecting the behavior; stakeholders (project proponent, EIA consultants, and EIA appraisal committee) do not play their role as mandated in applicable legislation. In other research, Nadlifatin et al., (2015) conducted a questionnaire survey and found that only $40 \%$ Indonesian Citizen intend to participate in the EIA process. These researches have shown how there needs to be a further investigation into the current public participation mechanism in Indonesia. 
With the overview, this paper aims to criticize whether the current regulation of public participation in Indonesia has addressed the possible informational asymmetry to effective monitoring. First, we discuss the background in section 1. Section 2 provides a theoretical foundation to explain how environmental monitoring can be hampered by possible informational asymmetry. Furthermore, we establish how public participation may benefit environmental monitoring and briefly discuss the development of public participation in Indonesia environmental management. Next section discusses the current public participation in environmental management in Indonesia and addresses the possible informational asymmetry. The last section will conclude the paper and deliver suggestions for future research on policy options.

\section{LITERATURE REVIEW}

This section is divided into three sub-sections. The first sub-section reviews the current perspective on public participation in environmental management. The second discusses the challenge of environmental monitoring from informational asymmetry theories explicitly. The third discusses the development of Indonesia's public participation in environmental management. The literature review aims to give some general background on the issues discussed.

\subsection{Public Participation in Environmental Management}

Public participation has been increasing in various sectors of environmental management ranging from monitoring, planning, and decision making also initiatives (Allen, 2004). As noted by several authors (Younge \& Fowkes, 2003; Stringer et al., 2007; Richards et al., 2004), increase in public participation has been linked to public skepticism of the complex, uncertain and impactful nature of environmental decision-making. This spike in public participation is also attributed to a more evidence-based policy making to achieve an understanding of the process, and its implications emerged (Morrison-Saunders \& Fischer, 2006), one of them is EIA (Bawole, 2013). Public participation in impact assessment primarily aims to understand community perceptions regarding the proposed activity and to resolve conflicts and reach consensus regarding that activity (Furia \& Wallace-Jones, 2000). Therefore, public participation is considered an essential and integral component of EIAs (Hartley \& Wood, 2005)

Glucker et al. (2013) and Webler et al. (1995) noted three rationales for public participation in EIAs: normative, substantive and instrumental. Firstly, the normative rationale is based on deliberative democratic principles such as influencing decisions, enhancing democratic capacity (Laird, 1993; Thompson, 1970; Barber, 1984), social learning (Marzuki, 2009; Blackstock et al., 2007; Fiorino, 1990; Laird, 1993), increasing transparency in decision making (Gauthier et al., 2011) and empowering marginalized groups and individuals (Shrader-Frechette, 1985). Several authors have noted how stakeholder participation may empower them through cogeneration of knowledge and use the knowledge. (Greenwood et al., 1993; Okali et al., 1994; Wallerstein, 1999). Secondly, the substantive rationale sees public participation as a means to improve the quality of the decision output by incorporating local information and knowledge. By augmenting local knowledge to decision making. (O'Faircheallaigh, 2007; Appiah-Oppoku, 2001), public participation may reveal social and political values that otherwise will not be acknowledged (Isaacson, 1986). In the context of EIA, public participation has been regarded as the best concrete way to deliver relevant information and inputs from those affected (Hartley \& Wood, 2005; Andre et al., 2006). Lastly, instrumental rationale believes public participation to resolve conflicts among stakeholders. By accommodating lay participation effectively makes risk decision-making more legitimate and leads to better results (Kraft, 1988), even if those decisions are technical in basis (Kasperson et al., 1992). Decisions will be perceived to be holistic and fair, accounting for a diversity of values and needs (Richards et al., 2004). 
Based on those rationales we can argue that public participation is undoubtedly crucial. However, public participation is still applied to various degrees of involvement according to objectives pursued (Brombal et al., 2017). Rowe \& Frewer (2000) noted that the lowest level of involvement is characterized by a top-down, one-way flow of information while the highest is characterized by dialogue and two-way information exchange. As noted by Liu et al. (2014), environmental decision-making though originally made by large-scale policies and strategic decisions, requires further engagement and empowerment toward lay citizens. On the other hand, Lawrence (2006) organizes participation in general policy-making on the basis of a synthesis of approaches in the literature into four forms: consultative (public contributes information to a central authority); functional (public contributes information and is also engaged in implementing decisions); collaborative (public works with government to decide what is needed and contributes knowledge) and transformative (local people make and implement decisions with support from "experts" where needed).

Several factors may limit the potential for the public to contribute to complex policy decisions, such as ignorance, attitudes, beliefs, and motivations (Ravetz, 1986; McCallum \& Santos, 1997). Community participation in the decision-making process may be perceived as irrelevant, because they do not have the required expertise to participate effectively and that informing the community of the benefits of the project is sufficient (Adomokay \& Sheate, 2004). This results in local communities' participation in EIAs to be rather rhetorical (Cunningham \& Tiefenbacher, 2008). In some cases, consultation is limited to government agencies and the developers; locals are denied access to vital documents in languages they understand; and public hearings held in faraway places to make the locals incapable of participating; and information offered to the participants is often scanty and general, inaccurate and laden with outdated data (Zubair et al., 2011; Cunningham \& Tiefenbacher, 2008; Almer \& Koontz, 2004). This often results in a mere tokenism of public participation that brings no influence over decision making. (Nadeem \& Fischer, 2011; Almer \& Koontz, 2004). Unless it is convinced that participation will involve some real influence over decision making, the public will be reluctant to participate. This reluctance may result in a general cynicism that hampers future efforts of public participation and ultimately threatens the legitimacy of government (Webler et al., 1995; Curran \& Hollander, 2008). Moreover, several authors have noted that participation has often been limited to project inception decisions and not into operational stages of projects may not influence the decision at all (Diduck \& Sinclair, 2002; O'Faircheallaigh, 2007). This prevents citizens from contributing to the scoping of the projects; As also noted by Bisset (2000), including communities in environmental decision making from the beginning of the process is more effective as they feel that their demands have been considered. This enables the communities' concerns and suggestions addressed properly (Adomokay \& Sheate, 2004).

\subsection{Informational Asymmetry in Public Monitoring of Environmental Management}

Monitoring has been defined by Spellerberg (2005) as "the systematic measurement of variables and processes over time" and "assumes that there is a specific reason for that collection of data, such as ensuring that standards are being met." Monitoring as viewed by Legg \& Nagy (2006), "informs when the system is departing from the desired state, measures the success of management actions, and detects effects of perturbations and disturbances." In the case of environmental management, monitoring activities include many different types of assessments of the ecosystems: (1) status assessment, (2) impact assessment, or (3) adaptive management (Stem et al., 2005). Monitoring activities also include different aspects of the ecosystem monitored: ecosystem composition, structure, or processes (Milne et al., 2006). The goal is to get the monitoring information to decision makers in a way that will be acknowledged as being useful and meaningful and ultimately considered in the decision-making process. (Conrad \& Daoust, 2008) Involving the locally based stakeholders in monitoring will both 
enhance management responses across spatial scales and improve the speed of decision-making to tackle current negative environmental trends at operational levels of resource management (Danielsen et al., 2010).

Hartley \& Wood (2005) identifies several commonly cited barriers to effective participation which includes: of public knowledge of planning, legal and waste licensing issues. This barrier is linked to the competence criterion because a general lack of expertise and an inability to understand the complex technical details associated with the planning applications was a significant factor preventing the public from interacting and participating effectively. This is enhanced by the fact that not all the information necessary to enable the public to participate effectively is readily understandable by the lay person. (Hartley \& Wood, 2005). Most information is not meaningful but requires interpretation and analysis. People will have a difficult time sorting through highly technical information. Indeed, information-gathering or labeling that is excessive or too detailed can easily confuse, mislead, or be used to manipulate consumers; it may make people misperceive risks, misallocate resources, and frustrate health, safety, and environmental objectives (Volokh, 2002). It has been suggested that information collected by community groups is not taken seriously by decision-makers due to questions regarding the credibility, non-comparability, and completeness of the data (Gouveia et al., 2004; Bradshaw, 2003). We can link all these barriers to what comprises the information level of a community, which consists of its concern for the environment, and the resources available to the segment, among other things (Newell \& Green, 1997).

Where there are significant differences in the levels of environmental concern among community members, information asymmetry may arise because of differences in the availability of resources. Because a firm typically knows more about the environmental impact of its products, processes (and the waste it releases into the environment) than the community. (Kulkarni, 2000) A firm driven by short-term wealth maximization may exploit the perceived information asymmetry across various community segments. Communities that are perceived as not having high levels of environmental concern or resources (Taylor, 1989) and information (Lahart, 1978) are likely to be subjected to environmental damages (Kaplan \& Norton, 1992; Kaplan \& Norton, 1993). Kulkarni (2000), departing from adverse selection (Akerlof, 1970) and moral hazard (Arrow, 1971), explains how the informational asymmetry between a firm and the community may be further reinforced by a firm's desire to act opportunistically. Adverse selection (or hidden knowledge) implies that a firm may, for instance, deliberately withhold information about the environmental impact of its products, processes, and waste from the community. It may also perhaps omit references to some of the environmentally sensitive attributes of its products, processes, and wastes while disclosing the information to the community. Moral hazard (or hidden action), on the other hand, refers to the tendency of a firm to deliberately manipulate or distort the information.

We follow Comyns et al. (2013), in different discerning types of information to the types of goods within the literature on information economics. Goods have been classified as search, experience or credence depending on whether and when it is possible to ascertain product quality. Search well as noted by (Nelson, 1970) differed from experience good between search and experience goods based on the method, timing (pre or post-purchase) and cost of information assimilation on product quality. If the cost of the search is unacceptably high, especially where the purchase price may not warrant this cost, it is easier for the consumer to determine quality by experiencing the good and therefore deciding on quality post-purchase. The third classification of good, credence proper, was described by (Darby \& Karni, 1973) as "credence qualities are those which, although worthwhile, cannot be evaluated in normal use. Instead, the assessment of their value requires additional costly information". In this case, it 
may not be possible to determine the quality of the product either before or after purchase as the expert knowledge required or the overall costs involved may be prohibitive.

In this case, environmental information laws work in two ways: they inform people of risks, and they work to change companies' behavior (either because of public pressure or because companies will preemptively change their processes to avoid having to face such pressure). Some supporters of such laws may believe that current levels of risk may be acceptable so long as people are fully informed (Pollock \& Whitelaw, 2005). For the establishment of a welldesigned monitoring program, a general and systematic framework is needed (Vos et al., 2000). Many ecologic monitoring systems lack clear purposes and operate without the use of a framework. A mere "knowing-what-is-going-on" argument often seems to motivate the effort, without a detailed plan for communication of results or methodology to link the results to managers. Monitoring in the absence of clear objectives and without the context of a framework can often lead to "data kleptomania," i.e., the uncontrolled desire to collect more data" (Hellawell, 1991). Volunteer organizations with scarce financial and personnel resources cannot risk such pitfalls. A more fruitful starting point is to consider monitoring as part of some integrated system with decision makers and managers engaged in the process. Therefore, a monitoring program should start with the endpoint to identifying the kinds of environmental information managers require to make good decisions (Vos et al., 2000).

\subsection{The Development of Public Participation in Previous Regulations in Indonesia}

By the heightening of the global acknowledge of environmental issues, Indonesia established further concerns within environmental regulation. In 1982, the Indonesian Parliament passed Law Number 4 the Year 1982, mandating EIAs (under the name AMDAL: Analisis Mengenai Dampak Lingkungan) in specific projects. In the early days of development, public participation in Indonesia was paid little attention and lacked legal implications in the environmental management as well as EIAs system. In the current situation, however, public participation has become a legal component of EIA legislation in Indonesia (Chen, 2013). Thus, EIAs considered an instrument to help avoid environmental problems (Appiah-Oppoku, 2001; Almer \& Koontz, 2004; Nadeem \& FIscher, 2011) in the planning period of a project.

Chen (2013) divides of EIA development in Indonesia into four stages; Non-legalization stage (1980-1992); Initial legalization stage (1993-1998); development stage (1999-2008) and refinement stage (2009-2012). The first stage of EIA development in Indonesia is firstly introduced on Article 16 Law Number 4 the Year 1982 which mandates EIA on every proposed plan with a possibly significant impact to the environment. Despite this, Law Number 4 the Year 1982 does not provide the specific provisions for the EIA to be applicable until further regulated in Government Regulation 29/1986 which marks the next stage of EIA development is. This Government Regulation started to give a brief look about the procedure and mechanism of EIA (Purnama, 2003). Non-Governmental Organizations (NGOs) had been acknowledged and had a right to participate as EIA review commission by Government Regulation 29/1986. In this stage, the government has not discussed further EIA mechanism, procedure, and public involvement. For instance, in this regulation, provides an opportunity for the public to express public opinion and advice, but no specific method is found in implementing it. To sum up, in the range of 1982-1990, EIA in Indonesia does not provide public to participate directly, since negligible attention was paid to public participation at that time. No opportunity for the public to participate in the EIA process nor the transparency of project document to the public (Chen, 2013).

Next stage of public participation in EIA begins with the enactment of Government Regulation Number 51 the Year 1993. As noted by (Chen, 2013) this regulation assumed to elucidate some ambiguities of the past regulation and make the AMDAL procedures more intelligible and 
specific. Thus, article 22 paragraph (3) states that transparency of AMDAL documents and the approvals open to the public and public can deliver their advice and opinions to AMDAL commission before the approval of AMDAL documents and the final decision is made. Even though the improvement of public participation and the disclosure of AMDAL documents could be seen, this regulation still lacks the focus on specific guidelines for participation. For example, this government regulation still limits the participation only to NGOs. As abovementioned, the recent EIA regulation already admitted NGOs as a temporary member of the AMDAL commission, no notable progress within this regulation in the context of direct public participation in AMDAL. By 1997, The enactment of Law Number 23 the Year 1997 concerning environmental management started the EIA development stage, bringing the disclosure of environmental information and documents as obligatory to the public. Furthermore, the Government Regulation Number 27 the Year 1999 which derives from Law Number 23 the Year 1997 accommodated what lacks on the previous have missed (51/1993). The significant progress of this regulation is the obligation of public involvement as AMDAL Reviewer Commission. This completely differs from public participation in AMDAL in the previous regulations (Regulation Number 29 the Year 1986 and Number 51 the Year 1993) did not have provisions for direct public involvement and admitted representation only to NGOs. Thus, Government Regulation Number 27 the Year 1999 has solved this issue.

\section{METHODS}

This paper is normative research, also known as legal literature research which is conducted by analyzing literature or secondary data that covers research on legal principles, the legal system, legal comparison, and legal history. (Soekanto \& Mamudji, 2007). Normative legal research is designated to assess the qualitative value of a legal norm. In this case, this paper will assess the current public participation in environmental management in Indonesia and the possible methods to resolve the problem. This paper uses a qualitative approach which aims to create an understanding regarding problems in the current public participation mechanism in environmental management in Indonesia.

The methods of data collection used in this paper are literature research/document study. The legal literature/documents used in this paper are divided into two types:

1. Primary Legal Source.

Primary legal sources are legally binding (Mamudji et al., 2005), which in this paper consists of:

a. Law Number 4, 1982

b. Law Number 23,1997

c. Law Number 32, 2009

d. Government Regulation Number 27, 2012 on Environmental Permit

e. Minister of Environment Regulation Number 9, 2010

f. Minister of Environment Regulation Number 5. 2012

g. Minister of Environment Regulation Number 17, 2012

h. Minister of Environment Regulation Number 2, 2013

2. Secondary Legal Source

Secondary legal source is materials that explain the primary legal source. (Mamudji, et al., 2005) Secondary legal source is needed as a theoretical base that will be used in this paper. This 
includes books, scientific journal articles, research reports, theses, and other literature related to the topic discussed.

\section{RESULTS AND DISCUSSION}

\subsection{Current Public Participation in Indonesia Environmental Management}

The promulgation of Government Regulation Number 27, 2012 on Environmental Permit and Minister of Environment Regulation Number 17 Year 2012 specify concerning Guideline on Public Participation in EIA, composed a new provision for public participation in EIA. Therefore, the provisions are more specific and comprehensive compared to the former regulations. The process of public participation considered to be more effective rather than superficial (Chen, 2013). Based on this, we identified several means for the public to participate in environmental management provided by Law Number 32, 2009. First is to include public to participate directly in AMDAL-mandatory projects. Second is General Public Participation. The third is the civil rights to report environmental pollution and damages. We exclude these participations from several legal standing provided to communities such as organizational standing, civil lawsuit, in both tort or administrative dispute.

\subsubsection{AMDAL Mandatory Projects}

AMDAL-mandatory projects are qualified by Article 22 Law Number 32, 2009 to give significant impact to the environment based on the following criteria: (1) the vast amount population affected by the activities; (2) areas affected; (3) intensity and length of the impact; (4) substantial environmental components affected; (5) cumulative impact; (6) impact reciprocity; (7) other criteria relevant to science and technology development. Minister of Environment further regulates the complete list of activities through Minister of Environment Regulation Number 05, 2012.

AMDAL documents consist of (a) Term of Reference (TOR) (known as Kerangka Acuan) (b) Environmental Impact Statement (EIS) (known as Analisis Dampak Lingkungan (Andal)) and (c) Environmental Management Plan-Environmental Monitoring Plan (EMP-EMoP) (known as Rencana Pengelolaan Lingkungan Hidup-Rencana Pemantauan Lingkungan Hidup (RKLRPL)). With the role of public participation in AMDAL, there are still several restrictions on who can participate in AMDAL mandatory project. This limits the participation only to the community of; affected groups; environmental observer; and whoever affected by any form of the decision in AMDAL process. This involvement in AMDAL is implemented through business/activity plan announcement and public consultation. In the AMDAL, a guideline for public involvement process is required to ensure that the rights and liabilities of the citizens in the sector of protection and environmental management are fulfilled. It is also used to make the process of any environmental activity permission more transparent, effective, accountable, and the results in the functional outcome. (Persada, et al., 2014).

Referring to the Minister Guidelines of Public Participation in EIA (Number 17, 2012), the public have five stages of participation: screening; scooping, The Agreement of Term of Reference (TOR), EIS and EMP-EMoP Planning and EIA decision. Firstly, the screening stage is comprised of: determining whether the projects bring significant impacts on the environment; mapping the affected areas and communities; and estimating the impact of one project (Chen, 2013). In the screening stage, there is no active participation by the public. However, project proponents must ensure the public to receive information regarding projects plan and contribute toward the AMDAL process through the announcement. Project proponents must disclose information regarding project location and the potential environmental impacts. The regulation mandates the project proponents to conduct the announcements through printed media such as newspapers and notice board easily accessible by affected community. Besides mandatory 
announcement, the regulation allows the project proponents to conduct the announcements through the brochure, pamphlet, banner; electronic media such as television, website, social media, SMS, Radio; notice board in the environmental department authorizing the project; or other forms of media.

In the scoping stage, the project proponent prepares the documents related impact identification, evaluation, classification, and priority. Then, in public consultation citizen may give advice, opinions as well as comments and will be consulted by the project developer. (Chen, 2013) This enables the public to inform the project developer about the environmental condition and local activities located near the projects, and the public aspiration. Project proponents must also conduct public consultation and may undertake it-before, simultaneously or after the announcement of the proposed project. Listed on public participation guidelines (Minister of Environment Regulation Number 17, 2012), public participation can be implemented in the form of a seminar, focus group discussion, citizen meeting, interactive dialog and other methods that can facilitate two-way communication. All Information derived from public participation must be implemented in the formation of TOR. All suggestions and opinions from the screening stage must be reflected in the TOR, EIS, and EMP-EMoP.

Furthermore, In the stages of the Agreement of TOR; EIS and EMP- EMoP Planning; and EIA decision, the public could no longer actively participate in environmental decision-making except through affected community representative in AMDAL commission (Chen, 2013). Affected community representative shall conduct communication and consultation regularly to the affected community, as well as deliver the aspirations from the community in AMDAL commission meeting-Concerning evaluate the feasibility or impropriety of one business/activity plan with significant impacts. There is not any details or specific criteria to qualify as a community representative in AMDAL commission. On the other hand, the affected community determines its representative by themselves. Although this regulation has met the shortcomings of the previous regulation, there is no guarantee that the suggestion given by the public will be considered and taken into consideration in the preparation of EIA.

\subsubsection{General Participation}

Besides the public participation mentioned above, there is another essential public involvement in both AMDAL Mandatory Projects and Environmental Management Effort-Environmental Monitoring Effort (EME-EMoE) (known as Usaha Pengelolaan Lingkungan Hidup-Usaha Pemantauan Lingkungan Hidup (UKL-UPL)). EME-EMoE Mandatory Projects. The form of participation begins with the announcement by governments agencies (national, provincial, or municipal) of any environmental license application. The announcement is made through multimedia effective in reaching the public or notice boards near the proposed project location or easily accessed by the affected community. For AMDAL Mandatory Projects, the announcement must at least contain 1) names and address of environmental license applicant; 2) types of proposed projects or activities; 3) scales of proposed projects or activities; 4) location of proposed projects or activities; 5) information regarding how to obtain the AMDAL Documents, consisting: location, download link; 6) Date of announcement and deadline of entry regarding advice, opinions, and comments; 7) name and address of government agencies receiving advice, opinions, and comments from public; 8) name and location of community representative and environmental organization in the AMDAL Commission. The announcement must be made within five working days since the completion of the environmental license application. The public will have ten working days since the announcement to give advice, opinions, or comments. 
While for the EME-EMoE Mandatory Projects, must at least contain: 1) names and address of environmental license applicant; 2) types of proposed projects or activities; 3) scales of proposed projects or activities; 4) location of proposed projects or activities; 5) information regarding how to obtain the EME-EMoE form filled by project proponents, consisting: location, download link; 6) Date of announcement and deadline of entry regarding advice, opinions, and comments; 7) name and address of government agencies receiving advice, opinions, and comments from public. The announcement must be made within two working days since the completion of the environmental license application. The public will have three working days since the announcement to give advice, opinions, or comments. Thus, the community may give advice, opinions and comments about the project proposed-in writing or recorded. Direct participation such as public consultation is no longer implemented under this mechanism. In both AMDAL and Non-AMDAL mechanism, All the inputs by the community during the license application process will be used as one of consideration in the process of environmental license issuance by the government. Lastly, the government agencies must announce the environmental license issued within five working days. The public opposing the environmental license can use the administrative, legal remedy to overturn the environmental license.

\subsubsection{Reporting}

Reports on environmental pollution or damages have been guaranteed as legal rights on Article 65 Law Number 32, 2009 on Protection and Conservation of Environment (hereafter referred to Environment Law). The rights are implemented further within Minister of Environment Regulation Number 9, 2010 which regulates the technical aspects of receiving and processing citizen reports. A citizen may deliver the reports orally or written towards governmental agency, whether municipal government, the provincial government, or the central government each according to their competence. Both oral and written reports must at least contain information regarding: (1) reporter's identity; (2) locations of environmental pollution or damages; (3) estimated source of environmental pollution or damages; (4) time of environmental pollution or damages; (5) affected environmental media. After receiving the reports, the government agency will then analyze and verify them. The results will then be processed into recommendation whether or not there will be sanctions or indictments. As specified in Article 3 of Minister of Environment Regulation Number 2, 2013, citizen report is one of the basis, besides direct monitoring, for a governmental agency to impose administrative sanctions. Lastly, the government will give the reporters the development and result of the report.

\subsection{Possible Informational Asymmetry in Current Public Participation in Indonesia Environmental Management}

We found that there are still gaps in access to relevant information in the current mechanism of public participation. This is due to a prematurely informational disclosure and the lack of projects and decisions follow-up towards the community by both firms and government agencies. This set a barrier for the community to obtain credence information which comprised of the firms' environmental requirements and obligations and the highly technical aspects of environmental monitoring. We shall argue how these methods of public participation do not enable the public to give effective monitoring of firms' compliance. It has been generally perceived that meaningful environmental reporting must be usable in decision-making (Conrad \& Daoust, 2008), in this case, imposing administrative sanctions. Article 3 of Minister of Environment Regulation Number 2, 2013 has specified that government agencies may impose administrative sanctions if there are violations toward Environmental License (Izin Lingkungan), Environmental Protection and Management License (Izin Perlindungan dan Pengelolaan Lingkungan Hidup), and environmental regulations. Environmental Licenses as 
specified in Article 48 Government Regulation Number 27, 2012 must at least contain requirements and regulations stated in the Environmental Appropriateness Decree (Keputusan Kelayakan Lingkungan Hidup), for AMDAL-mandatory projects, or EME-EMoE Recommendation, for Non-AMDAL Mandatory Projects. Government agencies may impose further requirements and obligations in the environmental licenses. From this, we can conclude that public participation in environmental monitoring must thus be able to identify whether firms have complied to the requirements and obligations set by government agencies. The problem is the required information on firms' compliance is highly technical and may be obscure to lay persons (Fiorino, 1990; Adomokay \& Sheate, 2004). Information needed to verify firms' compliance information into two aspects. First, is the information about firms' activities and the second is the information about firms' requirements and obligations.

We argue that these aspects of information fall into typologies of the information set by (Comyns et al., 2013), notably search, experience, and credence information. The most notable is firms' activities that will fall into search information. This information is made available when the start the activities that will give visible alteration on the environment. However, there might be information on firms' activities that will fall into experience and credence information. Experience information is made when the predicted impacts informed to the public happen or not happen. Lastly, the information on firms' activities may fall into credence information if it is highly technical for example the amount of pollution and emission made by firms. The second aspects which are the firms' information will all fall into credence information that if without any help the public may never know them.

As noted in the previous sub-section, public participation in Indonesia aims to include local knowledge and aspiration. In AMDAL-mandatory project, there is some information disclosure through announcement and public consultation before it started. However, the heart of the problem itself is located in the prematurely informational disclosure through the early public participation. We must note how the public participation and consultation is involved very early without any meaningful follow-up on the decision. The public is involved before the documents are even prepared. In this case, the public participation acts only as one of the data-gathering tools which must be implemented in the TOR. Moreover, the final follow-up regarding the decisions occurs only during the announcement made by the government agency before the license application and after license issuance. The lack of follow-up mechanism will hinder the public from getting enough information regarding the requirements and obligations imposed on firms that fell into the credence type of information. This will possibly foster informational asymmetry condition that will not guarantee firms' compliance.

In addition to this, we see very little intervention and presence from government agencies in regulating more technical aspects of public participation. For instances, there are not any obligations for government officials to attend public consultations. Lastly, the community representative in the AMDAL Commission lacks real qualification to give meaningful participation and receive vital information to be distributed to the public. Furthermore, the representation mechanism relies heavily on the people elected by the community to diminish the informational asymmetry. There is no guarantee that the representative may distribute meaningful information effectively to an even more lay public. As a result, the current mechanisms tend to rely on the bonafide nature of firms' and act to repress violation instead of preventing them. This proves to be a burden when we account the opportunistic nature of firms clashed with environmental protection (Kaplan \& Norton, 1992; Kaplan \& Norton, 1993; Kulkarni, 2000). As noted by (Kulkarni, 2000), firms have the opportunistic nature to impose adverse selection and moral hazard regarding environmental information. This, in turn, will not result in compliance or important informational disclosure pertinent to effective public participation (Hartley \& Wood, 2005). 


\section{CONCLUSION}

This paper has brought a different perspective to understand public participation in Environmental Monitoring in Indonesia. We have demonstrated how the current mechanism in public participation still lacks informational disclosure to enable effective monitoring. This is due to a prematurely informational disclosure and the lack of projects and decisions follow-up towards the community by both firms and government agencies. This set a barrier for the community to obtain credence information which comprised of the firms' environmental requirements and obligations and also the highly technical aspects of environmental monitoring. We suggest a proper way to address this obstacle by reforming public participation regulation. Based on our review, we noted how community participation proves to educate and empower the community in environmental management. This somehow has not been fully acknowledged by the government agencies in devising a more educating public participation. As noted our review, the current public participation only seeks to obtain information from the community and not to give information. However, our findings still need to be supported through further empirical research to confirm our supposition. Strong case-study research is required to give some practical insights which contrast from our normative analysis.

\section{REFERENCES}

Adomokay, R., Sheate, W.R., 2004. Community participation and environmental decisionmaking in the Niger Delta. Environmental Impact Assessment Review, Volume 24, pp. 495-518.

Akerlof, G.A., 1970. The market for 'Lemons': Quality uncertainty and the market mechanism. Quarterly Journal of Economics, Volume 84, pp. 488-500.

Allen, J.L., 2004. The global environment: an emerging world view. Environment, Volume 23.

Almer, H., Koontz, T., 2004. Public hearings for EIAs in post-communist Bulgaria: Do they work?. Environmental Impact Assessment Review, Volume 24, pp. 473-493.

Andre, P., Enserink, D., Connor, D., Croal, P., 2006. Public participation international best practice principles, Fargo: International Association for Impact Assessment.

Appiah-Oppoku, S., 2001. Environmental impact assessment in developing countries: the case of Ghana. Environmental Impact Assessment Review, Volume 21, pp. 59-71.

Arrow, K.J., 1971. Essays in the Theory of Risk Bearing. Amsterdam: s.n.

Barber, B., 1984. Strong Democracy: Participatory Politics for a New Age. Berkely: University of California Press.

Bawole, J.N., 2013. Public Hearing or 'Hearing Public'? An Evaluation of the Participation of Local Stakeholders in Environmental Impact Assessment of Ghana's Jubliee Oil Fields. Environmental Management, Volume 52, pp. 385-397.

Bisset, R., 2000. Methods of consultation and public participation. Environmental assessment in developing and transitional countries: principles, methods and practice. 149-160.

Blackstock, K. L., Kelly, G. J., Horsey, B. L., 2007. Developing and applying a framework to evaluate participatory research and sustainability. Ecological Economics, Volume 60, pp. 726-742.

Bradshaw, B., 2003. Questioning the credibility and capacity of community-based resource management. The Canadian Geographer, Volume 47, pp. 137-150.

Brombal, D., Moriggi, A., Marcomini, A., 2017. Evaluating public participation in Chinese Era. An integrated Public Participation Index and its application to the case of the New Beijing Airport. Environmental Impact Assessment Review, Volume 62, pp. 49-60. 
Chen, J., 2013. Public participation provisions in Environmental Impact Assessment (EIA) legal system Case studies in China, India and Indonesia. Haikou (Hainan): Utrecht University.

Chen, J., 2013. The public participation provisions in Environmental Impact Assessment (EIA) system case studies in China, India and Indonesia, s.l.: s.n.

Comyns, B., Figge, F., Hahn, T., Barkemeyer, R., 2013. Sustainability reporting: The role of "Search", "Experience" and "Credence" information. Accounting Forum, Volume 37, pp. 231-243.

Conrad, C., Daoust, T., 2008. Community-based monitoring frameworks: Increasing the effectiveness of environmental stewardship. Environmental Management, Volume 41, pp. 356-358.

Creighton, J., 1983. An overview to the research conference on public involvement and social impact assessment. Public involvement and social impact assessment. Westview Press, Boulder, Colorado, USA, 1-10.

Cunningham, C., Tiefenbacher, J.P., 2008. Evaluating the effectiveness of public participation efforts by environmental agencies: repermitting a smelter in El Paso, Texas, USA. Environment and Planning C: Government and Policy, 26(4), pp. 84-856.

Curran, G., Hollander, R., 2008. A tale of two pulp mills: realising ecologically sustainable development in Australia. Australian Journal of Public Administration, 67(4), pp. 483-497.

Danielsen, F., Burgess, N.D., Jensen, P.M., Pirhofer-Waizi, K., 2010. Environmental monitoring: the scale and speed of implementation varies according to the degree of people's involvement. Journal of Applied Ecology, Volume 47, pp. 1166-1168.

Darby, M.R., Karni, E., 1973. Free competition and the optimal amount of fraud. Journal of Law \& Economics, Volume 16, pp. 67-88.

Diduck, A., Sinclair, A., 2002. Public involvement in environmental assessment: the case of the nonparticipant. Environmental Management, Volume 29, pp. 578-588.

Fiorino, D.J., 1990. Citizen Particiption and Environmental Risk: A Survey of Institutional Mechanisms. Science, Technology, \& Human Values, 15(2), pp. 226-243.

Furia, L.D. Wallace-Jones, J., 2000. The effectiveness of provisions and quality of practices concerning public participation in EIA in Italy. Environmental Impact Assessment Review, Volume 20, pp. 457-479.

Gauthier, M., Simard, L., Waaub, J.P., 2011. Public participation in strategic environmental assessment (SEA): Critical review and the Quebec (Canada) approach. Environmental Impact Assessment Review, Volume 31, pp. 48-60.

Glucker, A.N., Driessen, P.P.J., Arend, K., Runhaar, H.A.C., 2013. Public participation in environmental impact assessment: why, who and how?. Environmental Impact Assessment Review, Volume 43, pp. 104-111.

Gouveia, C., Fonseca, A., Camara, A., Ferrira, F., 2004. Promoting the use of environmental data collected by concerned citizens through information and communication technologies. Journal of Environmental Management, Volume 71, pp. 135-154.

Greenwood, D.J., Whyte, W.F., Harkavy, I., 1993. Participatory action research as a process and as a goal. Human Relations, Volume 46, pp. 175-192.

Hartley, N., Wood, C., 2005. Public participation in environmental impact assessment implementing the Arhus Convention. Environmental Impact Assessment Review, Volume 25, pp. 319-340.

Hellawell, J., 1991. Development of a rationale monitoring. In Monitoring for conservation and ecology. London: Chapman and Hall, pp. 1-14.

Hindrayani, A., 2018. Public Participation Planning of Environmental Impact Assessment (EIA) and Regulations: Analysis of Inconsistency for Some Cases in Indonesia. In E3S Web of Conferences, vol. 31, p. 09020. EDP Sciences. 
Hughes, R., 1998. Environmental Impact Assessment and stakeholder involvement. Environmental Planning Issues, Volume 11.

Isaacson, P., 1986. Pollutant regulation and public sensibility. Environmental Impact Assessment Review, Volume 6, pp. 229-232.

Kaplan, R.S., Norton, D.P., 1992. The Balanced Scorecard - Measures that Drive Performance. Harvard Business Review, January-February.pp. 71-79.

Kaplan, R.S., Norton, D.P., 1993. Putting the Balanced Scorecard to Work. Harvard Business Review, September-October.pp. 134-147.

Kasperson, R.E., Golding, D., Tuler, S., 1992. Social distrust as a factor in siting hazardous facilities and communicating risks. Journal of Social Issues, Volume 48, pp. 161-87.

Kraft, M.E., 1988. Evaluating technology through public participation: The nuclear waste disposal controversy. In: M. E. Kraft \& N. J. Vig, eds. Technology and politics. Durham: Duke University Press, pp. 253-277.

Kulkarni, S.P., 2000. Environmental Ethics and Information Asymmetry among Organizational Stakeholders. Journal of Business Ethics, Volume 27, pp. 215-228.

Lahart, D.E., 1978. The Influence of Knowledge on Young People's Perceptions About Wildlife, Tallahassee: Florida State University.

Laird, F.N., 1993. Participatory analysis, democracy, and technological decision-making. Science, Technology, \& Human Values, 18(3), pp. 341-61.

Lawrence, A., 2006. No personal motive? Volunteers, biodiversity, and the false dichotomies of participation. Ethics, Place and Environment, 9(3), pp. 279-298.

Legg, C. J., Nagy, L., 2006. Why most conservation monitoring is, but need not be, a waste of time. Journal of Environmental Management, Volume 78, pp. 194-199.

Liu, H.Y., Kobernus, M., Broday, D., Bartonova, A., 2014. A conceptual approach to be citizens' observatory - supporting community-based environmental governance. Environmental Health, Volume 13, pp. 107-119.

Marzuki, A., 2009. A Review on Public Participation in Environmental Impact Assessment in Malaysia. Theoretical and Empirical Researches in Urban Management, 31(2), pp. 126136.

McCallum, D.B., Santos, S.L., 1997. Comparative risk analysis for priority setting. Human and Ecological Risk Assessment, 3(6), pp. 45-57.

Milne, R., Rosolen, S., Whitelaw, G., Bennett, L., 2006. Multi-party monitoring in Ontario: Challenges and emerging solutions. Environments, Volume 34, pp. 11-23.

Morrison-Saunders, A., Fischer, T., 2006. What is wrong with EIA and sea anyway? A sceptic's perspective on sustainability and assessment. Journal of Environmental Assessment Policy Management, Volume 8, pp. 19-39.

Nadeem, O., Fischer, T., 2011. An evaluation framework for effective public participation in EIA in Pakistan. Environmental Impact Assessment Review, Volume 31, pp. 36-47.

Nadlifatin, R., Razif, M., Lin, S.C., Persada, S.F., Belgiawan, P.F., 2015. An assessment model of Indonesian citizens' intention to participate on environmental impact assessment (EIA): A behavioral perspective. Procedia Environmental Sciences, 28, 3-10.

Nelson, P., 1970. Information and consumer behavior. Journal of Political Economy, Volume 78, p. 311.

Newell, S.J., Green, C.L., 1997. Racial Differences in Consumer Environmental Concern. Journal of Consumer Affairs, 31(1), pp. 53-69.

Newig, J., Fritsch, O., 2009. Environmental Governance: Participatory, Multi-level and Effectibve?. Environmental Policy and Governance, p. 200.

O'Faircheallaigh, C., 2007. Environmental agrements, EIA followup and aboriginal participation in environmental management: the Canadian experience. Environmental Impact Assessment Review, Volume 27, pp. 319-342. 
Okali, C., Sumberg, J., Farrington, J., 1994. Farmer Participatory Research. London: Intermediate Technology Publications.

Persada, S.F., Razif, M., Lin, S.C., Nadlifatin, R., 2014. Toward paperless public announcement on environmental impact assessment (EIA) through SMS gateway in Indonesia. Procedia Environmental Sciences, 20, 271-279.

Pollock, R.M., Whitelaw, G.S., 2005. Community-based monitoring in support of local sustainability. Local Environment, Volume 10, pp. 211-228.

Purnama, D., 2003. Reform of the EIA process in Indonesia: improving the role of public involvement. Environmental Impact Assessment Review, Volume 23, pp. 415-439.

Ravetz, J., 1986. Usable ignorance. In: W. C. Clarke \& R. E. Munn, eds. Sustainable development of the biosphere. Cambridge: Cambridge University Press.

Richards, C., Blackstock, K. L. \& Carter, C. E., 2004. Practical Approaches to Participation, Aberdeen: Macauley Land Use Research Institute.

Rowe, G., Frewer, L. J., 2000. Public Participation Methods: A Framework for Evaluation. Science, Technology, \& Human Values, 25(1), pp. 3-29.

Salomons, G.H., Hoberg, G., 2014. Setting boundaries of participation in environmental impact assessment. Environmental Impact Assessment Review, Volume 45, pp. 69-75.

Shepherd, A., 1997. Post-project impact assessment and monitoring. In: Environmental Methods Review: Retooling Impact Assessment for the New Century. Atlanta: Army Environmental Policy Institute.

Shepherd, A., Bowler, C., 1997. Beyond the Requirements: Improving Public Participation in EIA. Journal of Environmental Planning and Management, 40(6), pp. 725-738.

Shrader-Frechette, K.S., 1985. Risk analysis and scientific method: Methodological and ethics problems with evaluating societal risks. Boston: D. Reidel.

Spellerberg, I.F., 2005. Monitoring ecological change. Cambridge: Cambridge University Press.

Stem, C., Margoluis, R., Salafsky, N., Brown, M., 2005. Monitoring and evaluation in conservation: A review of trends and approaches. Conservation Biology, Volume 19, pp. 295-309.

Stringer, L.C., Reed, M.S., Dougill, A.J., Rokitzki, M., Seely, M., 2007. Enhancing participation in the implementation of the United Nations Convention to Combat Desertification. In Natural Resources Forum (Vol. 31, pp. 198-211).

Taylor, D.E., 1989. Blacks and the Environment: Toward an Explanation of the Concern Gasp Between Blacks and Whites. Environment and Behavior, 21(2), pp. 175-202.

Thompson, D.F., 1970. The democratic citizen: Social science: Social science and democratic theory in the twentieth century. Cambridge: Cambridge University Press.

Volokh, A., 2002. The Pitfalls of the Environmental Right-to-Know. Utah Law Review, pp. 805-841.

Vos, P., Meelis, E., Keurs, W. J., 2000. A framework for the design of ecological monitoring programs as a tool for environmental nature management. Environmental Monitoring and Assessment, pp. 217-244.

Wallerstein, N., 1999. Power between the evaluator and the community: research relationships within New Mexico's healthier communities. Social Science and Medicine, Volume 49, pp. 39-53.

Webler, T., Kastenholz, H., Renn, O., 1995. Public Participation in Impact Assessment: A Social Learning Perspective. Environmental Impact Assessment Review, Volume 15, pp. 443-463.

Whitelaw, G., Vaughan, H., Atkinson, D., 2003. Establishing the Canadian Community Monitoring Network. Environmental Monitoring and Assessment, Volume 88, pp. 409418. 
Younge, A., Fowkes, S., 2003. The cape action plan for the environment: overview of an ecoregional planning process. Biological Conservation, Volume 112, pp. 15-28.

Zubair, S., Bowen, D., Elwin, J., 2011. Not quite paradise: inadequacies of environmental impact assessment in the Maldives. Tourism Management, Volume 32, pp. 225-234. 